ISSN: 2302-8556

E-Jurnal Akuntansi Universitas Udayana

Vol.25.2.November (2018): 1099-1126

DOI: https://doi.org/10.24843/EJA.2018.v25.i02.p11

\title{
Pengaruh Komitmen, Kompetensi dan Good Corporate Governance pada Kinerja Keuangan
}

\author{
Putu Cintya Purnama Dewi ${ }^{1}$ \\ I Wayan Pradnyantha Wirasedana ${ }^{2}$
}

${ }^{1}$ Fakultas Ekonomi dan Bisnis Universitas Udayana (Unud), Bali, Indonesia
email: cintyad9@ gmail.com/Telp: 081933005680
${ }^{2}$ Fakultas Ekonomi dan Bisnis Universitas Udayana (Unud), Bali, Indonesia

\begin{abstract}
ABSTRAK
Rasio ROA ini dipilih karena ROA menunjukkan indikasi realistis kinerja perusahaan karena menunjukkan efisiensi total aset untuk menghasilkan keuntungan Penelitian ini dilakukan di Lembaga Perkreditan Desa (LPD) Se- Kecamatan Abiansemal Kabupaten Badung.Jumlah sampel yang diambil sebanyak 34 LPD dengan masing-masing ketua LPD sebagai responden penelitian.Teknik analisis data yang digunakan dalam penelitian ini yaitu teknik analisis regresi linier berganda. Berdasarkan hasil analisis ditemukan bahwa komitmen, kompetensi dan good corporate governanceberpengaruh signifikan pada kinerja keuangan LPD.Hal ini menunjukkan bahwa apabila komitmen dan kompetensi karyawan semakin baik maka berimplikasi pada semakin baik pula kinerja keuangan LPD.Semakin baik penerapan good corporate governance maka semakin baik pula kinerja keuangan LPD. Penelitian ini juga menjelaskan bahwa komitmen, kompetensi dan good corporate governance wajib di terapkan sehingga terciptanya solusi yang akan mempermudah LPD maupun perusahaan perbankan lainnya dalam meningkatkan kinerjanya untuk meningkatkan kesejahteraan masyarakat maupun lembaga yang terkait.
\end{abstract}

Kata Kunci: Komitmen, kompetensi, good corporate governance, kinerja keuangan.

\begin{abstract}
This research was conducted at Lembaga Perkreditan Desa (LPD) of Abiansemal Subdistrict of Badung Regency. The number of samples taken as many as 34 LPD with each chairman of LPD as respondent research. Data analysis technique used in this research is multiple linear regression analysis technique. Based on the results of the analysis found that commitment, competence and good corporate governance significant influence on the financial performance of LPD.Hal indicates that if the commitment and competence of employees the better then the implications on the better the financial performance of LPD.Semakin good corporate governance implementation the better the performance financial LPD. This research also explains that commitment, competence and good corporate governance must be applied to create a solution that will facilitate LPD and other banking companies in improving their performance to improve the welfare of society and related institutions.
\end{abstract}

Kata Kunci: Komitmen, kompetensi, good corporate governance, financial performance.

\section{PENDAHULUAN}

Lembaga Perkreditan Desa adalah lembaga keuangan non bank yang dibentuk oleh Desa Pakraman dan memiliki fungsi dalam pemberdayaan ekonomi krama Desa Pakraman. Krama Desa yaitu mereka yang menetap pada Desa Pakraman 
Putu Cintya Purnama Dewi dan I Wayan Pradnyantha Wirasedana. Pengaruh...

dan menjadi warga pada Desa tersebut dan mempunyai ikatan adat istiadat dan budaya. Tujuan dibentuknya lembaga ini yakni untuk membantu krama Desa Pakraman dalam pembangunan perekonomian melalui tabungan yang terarah dan pemberian modal efektif.

Peran pengelola LPD sangat menentukan tingkat kesehatan LPD itu sendiri.Pengelola LPD yang terpisah dengan krama Desa tidak menutup kemungkinan adanya tindakan mementingkan diri sendiri di pihak pengelola LPD (agent) dan mengabaikan kepentingan krama Desa (principal) yang sering dikenal dengan konflik keagenan. Menurut teori keagenan, pemilik perusahaan dapat membatasi perbedaan kepentingannya dengan menetapkan intensif yang tepat bagi agen dan dengan menimbulkan biaya monitoring dirancang untuk membatasi tindakan agen (Hill dan Jones, 1992). Menerapkan sistem tata kelola perusahaan yang baik (good corporate governance) sangat diperlukan untuk mengurangi terjadinya konflik keagenan. Menurut Oliver (1995), corporate governance muncul dalam organisasi disebabkan karena adanya masalah agensi atau konflik kepentingan yang melibatkan anggota organisasi.

Penelitian ini menggunakan ROA untuk mengukur kinerja keuangan khususnya profitabilitas, sehingga dengan meningkatkan ROA berarti laba perusahaan juga meningkat. Untuk mengetahui faktor-faktor yang mempengaruhi kinerja keuangan perbankan yang diproksi dengan rasio Return On Asets. Return On Asets (ROA) digunakan untuk mengukur efektifitas perusahaan dalam menghasilkan keuntungan dengan memanfaatkan aktiva yang dimilikinya. Semakin besar ROA menunjukkan kinerja keuangan semakin baik, karena tingkat 
pengembalian semakin besar. Apabila ROA meningkat, berarti profitabilitas perusahaan meningkat, sehingga dampak akhirnya yaitu peningkatan profitabilitas yang dinikmati oleh pemegang saham (Husnan, 1998: 557).

Komitmen merupakan dorongan dari dalam individu untuk melakukan sesuatu agar dapat menunjang keberhasilan organisasi dan sesuai dengan tujuan yang telah ditetapkan dan lebih mengutamakan kepentingan organisasi. Karyawan atau anggota organisasi yang memiliki komitmen yang kuat agar bekerja dengan maksimal agar organisasi tempat mereka bekerja dapat mencapai keberhasilan bekerja dengan maksimal. Tanpa adanya dukungan dari komitmen organisasi penerapan good corporate governance tidak akan terlaksana dalam menghasilkan kinerja karyawan yang lebih baik.

Faktor yang tidak kalah penting berpengaruh pada kinerja keuangan selain komitmen adalah kompetensi. Enceng dkk (2008) menyatakan bahwa kompetensi merupakan pengetahuan, keterampilan, dan kemampuan yang dikuasai oleh seseorang yang telah menjadi bagian dari dirinya, sehingga ia dapat melakukan perilaku-perilaku kognitif, afektif, dan psikomotorik dengan sebaik-baiknya. Kompetensi tidak hanya mengandung keterampilan, pengetahuan, dan sikap, tetapi yang penting adalah penerapan dari keterampilan, pengetahuan, dan sikap mereka sesuai standar kinerja yang ditetapkan. Kompetensi dapat memperdalam dan memperluas kemampuan kerja. Semakin sering seseorang melakukan pekerjaan yang sama, semakin terampil dan semakin cepat pula dia menyelesaikan pekerjaan tersebut. Semakin banyak macam pekerjaan yang dilakukan seseorang, pengalaman kerjanya semakin kaya dan luas, dan memungkinkan peningkatan 
Putu Cintya Purnama Dewi dan I Wayan Pradnyantha Wirasedana. Pengaruh...

kinerjanya (Simanjuntak, 2005 : 113). Kompetensi seseorang menunjukkan jenisjenis pekerjaan yang pernah dilakukan seseorang dan memberikan peluang yang besar bagi seseorang untuk melakukan pekerjaan yang lebih baik.Semakin luas pengalaman kerja seseorang, semakin trampil melakukan pekerjaan dan semakin sempurna pola berpikir dan sikap dalam bertindak untuk mencapai tujuan yang telah ditetapkan (Abriyani, 2004).

Hal menarik yang perlu diteliti yaitu ketika melihat perusahaan perbankan yang baru berdiri dan perusahaan perbankan yang kondisinya tidak sehat tentu membutuhkan tata kelola perusahaan yang kuat sehingga mendapatkan dukungan dalam perkembangan perusahaan tersebut. Pihak terkait meyakini bahwa GCG merupakan konsep pengolahan usaha yang mampu menyatukan arah perusahaan dan kesimbangan antara kekuatan kewenangan yang diperlukan oleh perusahaan untuk menjalin kelangsungannya dan bertanggung jawab kepada stakeholder serta mencapai visi misi perusahaan. Dalam penelitian yang dilakukan oleh Sari (2010), Setyawan (2013), tentang pengaruh GCG terhadap kinerja keuangan menunjukkan bahwa GCG memiliki pengaruh positif terhadap kinerja keuangan.Hasil penelitian tersebut bertentangan dengan penelitian sebelumnya yang dilakukan oleh Purwani (2010) yang menyatakan, bahwa GCG tidak berpengaruh secara langsung terhadap kinerja perusahaan.

Adapun rumusan masalah dalam penelitian ini yaitu Apakah komitmen berpengaruh pada kinerja keuangan? Apakah kompetensi berpengaruh pada kinerja keuangan? Apakah good corporate governance berpengaruh pada kinerja keuangan? 
Menurut Lubis (2011:91), teori agensi didasarkan pada teori ekonomi. Dari sudut pandang teori agensi, principal (pemilik atau manajemen puncak) membawahi agent (karyawan atau manajer yang lebih rendah) untuk melaksanakan kinerja yang efisien. Teori ini mengasumsikan kinerja yang efisien dan kinerja organisasi ditentukan oleh usaha dan pengaruh kondisi lingkungan. Menurut Eisenhardt (1989) teori keagenan didefinisikan sebagai adanya hubungan keagenan, dimana suatu pihak tertentu (principal) mendelegasikan tugas kepada pihak lain (agent) untuk melakukan suatu pekerjaan. Lebih lanjut dijelaskan bahwa teori keagenan tersebut dapat dibagi menjadi dua yaitu : (1) Positive agency research, yaitu memfokuskan pada identifikasi situasi dimana agent dan principal mempunyai tujuan yang bertentangan dan mekanisme pengendalian yang terbatas hanya menjaga perilaku self serving agent. (2) Principal agent research, yaitu memfokuskan pada kontrak optimal antara perilaku dan hasilnya, secara garis besar penekanan pada hubungan principal agent.

Berkaitan dengan penelitian ini yang bertindak sebagai principal yaitu Desa Pakraman yang merupakan pemilik dari LPD. Dari segi pengelolaannya Desa Pakraman mendelegasikan tugas pengelolaan LPD kepada pengurus LPD yang bertindak sebagai agent. Adanya pelimpahan tugas dari principal ke agent ini, telah menimbulkan adanya hubungan keagenan. Dengan adanya hubungan keagenan antara krama Desa Pakraman dengan pengelola LPD memungkinkan timbulnya permasalahan - permasalahan seperti asimetri informasi dan konflik kepentingan. 
Putu Cintya Purnama Dewi dan I Wayan Pradnyantha Wirasedana. Pengaruh...

Robbins dan Judge (2007) mendefinisikan komitmen sebagai suatu keadaan dimana seorang individu memihak organisasi serta tujuan-tujuan dan keinginannya untuk mempertahankan keanggotaannya dalam organisasi. Mathis dan Jackson dalam Sopiah (2008) mendefinisikan komitmen organisasional sebagai derajat dimana karyawan percaya dan mau menerima tujuan-tujuan organisasi dan akan tetap tinggal atau tidak akan meninggalkan organisasinya. Argyris dalam Sukarno dan Prasetyohadi (2004) membagi komitmen menjadi dua, yaitu komitmen internal dan komitmen eksternal.

Komitmen internal merupakan komitmen yang berasal dari diri karyawan untuk menyelesaikan berbagai tugas, tanggung jawab dan wewenang berdasarkan pada alasan dan motivasi yang dimiliki. Komitmen eksternal dibentuk oleh lingkungan kerja, yang muncul karena adanya tuntutan terhadap penyelesaian tugas dan tanggung jawab yang harus diselesaikan oleh para karyawan. Usaha untuk menjelaskan rahasia kesuksesan bisnis bahwa cara terbaik untuk memotivasi orang-orang mencapai komitmen penuh pada nilai-nilai organisasi adalah melalui kepemimpinan (leadership) dan keterlibatan. Pendekatan ini seringkali disebut pendekatan Heart and Minds (Armstrong, 1999).

Purwanto (2006:8) mengemukakan bahwa kompetensi adalah suatu persyaratan kemampuan dalam melaksanakan jabatan. Biasanya kemampuan ini dikaitkan dengan keahlian, keterampilan atau profesionalisme, kompetensi jabatan fungsional, demikian juga dengan kompetensi jabatan negara/politik jauh berbeda dengan jabatan structural. Kompetensi merupakan karakteristik mendasar individu secara kasual berhubungan dengan efektivitas atau kinerja yang sangat baik. 
Pengertian dari Good Corporate Governance (GCG) tidak lain merupakan pengelolaan bisnis yang melibatkan kepentingan stakeholders serta penggunaan sumber daya yang berprinsipkan keadilan, efisiensi, transparansi dan akuntabilitas (Wardani, 2010). Hal tersebut, dalam keberadaanya penting dikarenakan oleh dua hal.Pertama, cepatnya perubahan yang berdampak pada persaingan global. Kedua, karena semakin banyak dan kompleksitas stakeholders termasuk struktur kepemilikan bisnis. Dua hal tersebut menyebabkan stress, resiko terhadap bisnis yang menuntut antisipasi peluang, dan ancaman dalam strategi termasuk sistem pengendalian yang prima.

Good Corporate Governance tercipta apabila terjadi keseimbangan kepentingan antara semua pihak yang berkepentingan dalam bisnis.Identifikasi keseimbangan dalam keberadaanya memerlukan sebuah sistem pengukuran yang dapat menyerap setiap dimensi strategis dan operasional bisnis serta berbasis informasi.Good Corporate Governance memberikan kontribusi yang dapat dijadikan sebagai alternatif penting untuk meningkatkan kualitas proses bisnis melalui informasi yang dihasilkan serta peranannya sebagai performance driver, performance measurement. Proses bisnis diperbaiki secara tepat dan akurat apabila diperoleh informasi yang akurat dan komprehensif tentang apa yang harus diperbaiki termasuk apa yang harus dilakukan.

Kinerja keuangan merupakan salah satu alat ukur yang digunakan oleh para pemakai laporan keuangan dalam mengukur atau menentukan sejauh mana kualitas perusahaan. Menurut Pratiwi et al, (2015) hasil kinerja dapat diukur dan menggambarkan kondisi perusahaan pada saat itu, untuk itu diperlukan penilaian 
Putu Cintya Purnama Dewi dan I Wayan Pradnyantha Wirasedana. Pengaruh...

dan pengukuran terhadap kinerja yang telah dilakukan perusahaan. Sektor keuangan merupakan salah satu sektor yang berpengaruh dalam operasional perusahaan (Hayati et al., 2009). Kinerja suatu perusahaan dapat dilihat dari laporan keuangan perusahaan tersebut.Dari laporan keuangan tersebut, dapat diketahui keadaan financial dari hasil - hasil yang telah dicapai perusahaan selama periode tertentu (Krismaya, 2014). Menurut Haque (2008) sangat penting bagi perusahaan untuk membuat informasi keuangan dan non keuangan agar mudah diakses oleh orang luar sehingga dapat membuat keputusan dengan baik.

Profitabilitas adalah rasio keuangan yang dapat dipergunakan untuk mengukur bagaimana kemampuan yang dimiliki oleh perusahaan dalam menghasilkan laba, baik dengan total aktiva yang dimiliki, penjualan maupun modal sendiri. Wiagustini (2014:86) menyatakan bahwa profitabilitas menunjukkan kemampuan perusahaan memperoleh laba atau ukuran efektifitas pengelolaan manajemen perusahaan. Profitabilitas perusahaan umumnya dianggap sebagai prasyarat penting untuk keberhasilan dan kelangsungan hidup perusahaan dalam jangka panjang.

Profitabilitas suatu bank dapat dinilai secara khusus maupun luas. Secara khusus, keuntungan merupakan syarat mutlak dari lembaga perbankan dan secara luas, lembaga keuangan yang menguntungkan akan mampu membuat sistem perekonomian satu Negara menjadi kuat dan berkembang (Ali et al. 2011). Jika dikaitkan dengan keberadaan LPD, maka LPD yang memiliki kemampuan dalam menghasilkan laba yang baik, akan memberikan dampak pada sistem 
perekonomian di daerah tempat LPD berada menjadi semakin kuat dan berkembang.

Lembaga Perkreditan Desa adalah lembaga ekonomi desa yang dipergunakan untuk penitipan dan penukaran uang di pedesaan. Sehingga pada dasarnya LPD berfungsi sebagai pengumpulan dana, pemberi kredit, dan menjadi perantara didalam lalu lintas pembayaran pada umumnya dan merupakan sumber pembiayaan pembangunan di wilayah desa adat yang ada di Bali. Lembaga Perkreditan Desa (LPD) merupakan lembaga keuangan milik desa pekraman yang telah berkembang, memberi manfaat sosial, ekonomi dan budaya kepada anggotanya, sehingga perlu dibina, ditingkatkan kinerjanya, dan diperkuat serta dilestarikan keberadaanya (Suartana, 2009:12).

Komitmen merupakan suatu hubungan antara anggota dengan organisasi. Sopiah (2008:155) mendefinisikan komitmen sebagai suatu ikatan psikologis karyawan pada organisasi yang ditandai dengan adanya kepercayaan dan penerimaan yang kuat atas tujuan dan nilai-nilai organisasi, kemauan untuk mengusahakan tercapainya kepentingan organisasi dan keinginan yang kuat untuk mempertahankan kedudukan sebagai anggota organisasi.

Dalam hubungan ini Eisenhardt (1989) menyatakan bahwa teori keagenan dilandasi oleh asumsi - asumsi, yaitu asumsi tentang sifat manusia, asumsi keorganisasian, dan asumsi informasi. Asumsi sifat manusia menekankan bahwa manusia memiliki sifat mementingkan diri sendiri (self-interest), memiliki keterbatasan rasional (bounded radionality), dan tidak menyukai risiko (risk aversion). Asumsi keorganisasian adalah adanya konflik antara anggota 
Putu Cintya Purnama Dewi dan I Wayan Pradnyantha Wirasedana. Pengaruh...

organisasi, efisiensi sebagai kriteria efektivitas dan adanya asimetri informasi antara principal dan agen.

Kusumasari dkk 2017 melakukan penelitian yang bertujuan untuk menguji pengaruh penerapan prinsip-prinsip good corporate governance, komitmen organisasi, gaya kepemimpinan dan pengawasan internal terhadap kinerja Lembaga Perkreditan Desa menyatakan komitmen organisasi berpengaruh positif dan signifikan terhadap kinerja Lembaga Perkreditan Desa.

Teori keagenan membahas adanya konflik kepentingan antara agen dengan principal, dan konflik tersebut menjadi pemicu pergantian manajemen (Jansen dan Meckling, 1976). Kesulitan bagi principal untuk memastikan apakah agen sebenarnya telah bertindak untuk memaksimumkan kesejahteraan principal.Setiap organisasi dibentuk untuk mencapai tujuan tertentu, dan apabila tercapai belum dapat dikatakan berhasil. Untuk mencapai keberhasilan, diperlukan landasan yang kuat berupa kompetensi. Dengan demikian, kompetensi menjadi sangat berguna untuk membantu organisasi meningkatkan kinerjanya.Semakin banyak kompetensi dipertimbangkan, maka semakin meningkat pula kinerjanya.

Yudistira dan Siwantara (2012) menyebutkan bahwa kompetensi berpengaruh positif dan signifikan secara langsung terhadap kinerja karyawan. Hal ini didukung oleh penelitian dari Sulistyaningsih (2009) bahwa kompetensi berpengaruh positif terhadap kinerja karyawan.

Berkaitan dengan teori agensi, menurut Jensen dan Meckling (1976), agency relationship didefinisikan sebagai suatu perjanjian kontrak antara satu atau beberapa orang pemilik modal (principal) dengan pihak lain yang disebut sebagai 
manajer (agent) untuk melakukan suatu kegiatan demi kepentingan principal. Namun pada dasarnya hubungan keagenan ini juga dapat menimbulkan masalah seperti konflik kepentingan antara principal dengan agent. Timbulnya masalah keagenan ini akan berdampak pada sistem tata kelola perusahaan yang tidak sesuai dengan prinsip-prinsip yang berlaku pada perusahaan. Solusi yang dapat diberikan untuk meminimalisir masalah keagenan ini yaitu dengan menerapkan praktik good corporate governance.

Berdasarkan hasil penelitian Hindistari (2016) menyatakan bahwa prinsipprinsip good corporate governance berpengaruh signifikan terhadap kinerja Bank Perkreditan Rakyat Kabupaten Gianyar.

\section{METODE PENELITIAN}

Data kuantitatif dalam penelitian ini adalah nilai atau skor atas jawaban yang diberikan oleh responden terhadap pernyataan-pernyataan yang ada dalam kuisioner penelitian serta jumlah LPD, jumlah karyawan LPD, jumlah Desa Adat yang ada di Kabupaten Badung yang diperoleh dari LPLPD Kabupaten Badung. Data kualitatif dalam penelitian ini adalah daftar nama LPD yang berada di Kecamatan Abiansemal Kabupaten Badung yang diperoleh dari LPLPD Kabupaten Badung.

Data primer dalam penelitian ini meliputi hasil jawaban responden yang diperoleh secara langsung melalui kuesioner yang dibagikan pada setiap responden penelitian. Data sekunder dalam penelitian ini meliputi laporan keuangan LPD Se-Kecamatan Abiansemal yang diperoleh dari LPLPD Kabupaten Badung. 
Putu Cintya Purnama Dewi dan I Wayan Pradnyantha Wirasedana. Pengaruh...

Populasi dalam penelitian ini adalah Seluruh LPD yang masih beroperasi di Kecamatan Abiansemal, Kabupaten Badung. Wilayah ini dipilih karena dari 34 Desa Adat yang ada di Kecamatan Abiansemal, seluruhnya telah memiliki LPD dan merupakan wilayah dengan dengan jumlah LPD terbanyak ke-2 yang ada di Kabupaten Badung. Daftar LPD di Kecamatan Abiansemal Kabupaten Badung dapat dilihat dalam table 1.

Tabel 1.

\begin{tabular}{cccc}
\multicolumn{4}{c}{ Daftar Nama LPD Kecamatan Abiansemal Kabupaten Badung } \\
\hline No & Nama LPD & No & Nama LPD \\
\hline 1 & Abiansemal & 18 & Lambing Mekarbhuana \\
2 & Ambengan & 19 & Lambing Sibang Gede \\
3 & Angantaka & 20 & Mambal \\
4 & Ayunan & 21 & Pikah \\
5 & Batubayan & 22 & Punggul \\
6 & Baturning & 23 & Samu \\
7 & Bindu & 24 & Sangeh \\
8 & Blahkiuh & 25 & Sedang \\
9 & Bongkasa & 26 & Selat \\
10 & Darmasaba & 27 & Semana \\
11 & Gerana & 28 & Sibang Gede \\
12 & Gerih & 29 & Sibang Kaja \\
13 & Jagapati & 30 & Sigaran \\
14 & Jempeng & 31 & Taman \\
15 & Karang Dalem & 32 & Tegal \\
16 & Kekeran & 33 & 34 \\
17 & Kutaraga & & \\
\hline 4 & & 32 & \\
\hline
\end{tabular}

Sumber: LPLPD Kabupaten Badung, 2017 
Teknik penentuan sampel yang digunakan dalam penelitian ini adalah teknik non probability sampling yang meliputi sampling jenuh, dimana dalam teknik ini semua anggota populasi digunakan sebagai sampel. Sehingga didapat jumlah sampel penelitian ini yaitu 34 sampel dengan masing-masing ketua LPD sebagai responden penelitian. Metode pengumpulan data yang digunakan dalam penelitian ini adalah kuesioner, wawancara dan observasi non participant.

Alat analisis data yang digunakan adalah statistic inference yang bertujuan untuk menguji hipotesis dengan menggunakan Regresi Linier Berganda melalui program komputer SPSS dengan rumus sebagai berikut.

$$
\mathrm{Y}=\mathrm{a}+\mathrm{b}_{1} \mathrm{X}_{1}+\mathrm{b}_{2} \mathrm{X}_{2}+\mathrm{b}_{3} \mathrm{X}_{3}+\mathrm{e}
$$

Dimana :

$$
\begin{array}{ll}
\mathrm{Y} & =\text { Variabel terikat (kinerja keuangan) } \\
\mathrm{a} & =\text { Konstanta } \\
\mathrm{b}_{1}, \mathrm{~b}_{2}, \mathrm{~b}_{3} & =\text { Koefisien regresi untuk } \mathrm{X}_{1}, \mathrm{X}_{2}, \mathrm{X}_{3} \\
\mathrm{X}_{1} & =\text { Variabel bebas (komitmen) } \\
\mathrm{X}_{2} & =\text { Variabel bebas (kompetensi) } \\
\mathrm{X}_{3} & =\text { Variabel bebas (good corporate governance) } \\
\mathrm{e} & =\text { Kesalahan pengganggu (Standar Error) }
\end{array}
$$

\section{HASIL DAN PEMBAHASAN}

Sampel yang digunakan dalam penelitian ini berjumlah 34 sampel yang merupakan seluruh LPD yang ada di Kecamatan Abiansemal Kabupaten Badung. Setiap LPD diberikan masing-masing satu kuesioner yang disi oleh masingmasing ketua LPD yang merupakan responden penelitian. Ketua LPD dipipilih sebagai responden penelitian dikarenakan ketua LPD yang paling bertanggung jawab atas pengelolaan LPD. Pengiriman kuisioner dilakukan dengan cara datang dan memberikannya secara langsung kepada 34 LPD Se-Kecamatan Abiansemal. 
Berikut adalah rincian pengisian pengiriman dan pengembalian kuisioner yang disajikan dalam Tabel 2.

Tabel 2.

Rincian Pengiriman dan Pengembalian Kuesioner

\begin{tabular}{lcc}
\hline \multicolumn{1}{c}{ Keterangan } & Jumlah & Persentase (\%) \\
\hline Kuesioner dikirim & 34 & 100 \\
Tidak kembali & 0 & 0 \\
Total kembali & 34 & 100 \\
Kuesioner tidak lengkap & 0 & 0 \\
Kuesioner yang digunakan & 34 & 100 \\
Tingkat Pengembalian (respon rate) & \multicolumn{2}{c}{$(34 / 34 \times 100 \%=100 \%$} \\
\hline Sumber : Data diolah, 2017 & &
\end{tabular}

Berdasarkan Tabel 2. di atas dapat dilihat bahwa dari 34 kuesioner yang dikirim, seluruhnya telah kembali dan bisa digunakan dalam penelitian ini sehingga persentase pengembaliannya 100\%. Dalam penelitian ini responden penelitian dibagi ke dalam beberapa karakteristik, mulai dari jenis kelamin, usia serta tingkat pendidikan. Berikut merupakan data mengenai karakteristik responden penelitian yang termuat dalam Tabel 3.

Tabel 3.

Karakteristik Responden Penelitian

\begin{tabular}{lcc}
\multicolumn{1}{c}{ Keterangan } & Jumlah & Persentase \\
\hline Jenis Kelamin & & \\
Laki-laki & 24 & $71 \%$ \\
Perempuan & 10 & $29 \%$ \\
Jumlah & 34 & $100 \%$ \\
Usia & & \\
$21-30$ tahun & 1 & $3 \%$ \\
$31-40$ tahun & 7 & $20 \%$ \\
$41-50$ tahun & 19 & $56 \%$ \\
51-60 tahun & 5 & $15 \%$ \\
>0 tahun & 2 & $6 \%$ \\
Jumlah & 34 & $100 \%$ \\
Pendidikan Terakhir & & \\
SMA/SMK & 17 & $50 \%$ \\
Diploma & 2 & $6 \%$ \\
Sarjana & 15 & $04 \%$ \\
Pasca Sarjana & 0 & $0 \%$ \\
Jumlah & 34 & \\
Sumber : Data Diolah, 2017 & &
\end{tabular}


Berdasarkan Tabel 3. di atas, dapat dijelaskan uraian karakteristik responden bahwa Jenis kelamin digunakan untuk mengetahui proporsi responden laki-laki dan perempuan pada LPD se-Kecamatan Abiansemal. Responden yang berjenis kelamin laki-laki berjumlah 24 orang (71\%) dan responden yang berjenis kelamin wanita sebanyak 10 orang (29\%).

Usia digunakan untuk mengetahui rentang usia responden penelitian pada LPD se-Kecamatan Abiansemal. Sebanyak 1 orang responden dengan usia 21-30 tahun, 7 orang dengan usia 31-40 tahun, 19 orang dengan usia 41-50 tahun, 5 orang usia 51-60 tahun, dan 2 orang dengan usia lebih dari 60 tahun.

Tingkat pendidikan digunakan untuk mengetahui pendidikan terakhir responden penelitian yang ada di LPD Se-Kecamatan Abiansemal. Sebanyak 17 orang pendidikan terakhirnya SMA/SMK, 2 orang pendidikan terakhirnya diploma, 15 orang pendidikan terakhirnya sarjana serta tidak ada responden yang pendidikan terakhirnya pasca sarjana.

Untuk mengukur validitas dalam penelitian ini dilakukan dengan koreksi bivariate antar masing-masing skor indikator dengan total skor konstruk (Correlation Coeficients Pearson) melalui program SPSS (Statistical Product and Service Solution). Hasil pengujian validitas instrumen ditunjukkan pada Tabel 4. sebagai berikut.

Tabel 4. Hasil Pengujian Instrumen

\begin{tabular}{cccccc}
\hline No & Variabel & Indikator & $\begin{array}{c}\text { Nilai } \\
\text { Correlation }\end{array}$ & Signifikansi & Keterangan \\
\hline 1 & Komitmen & $\mathrm{X}_{1.1}$ & 0,893 & 0,000 & Valid \\
& $\mathrm{X}_{1.2}$ & 0,799 & 0,000 & Valid \\
& $\mathrm{X}_{1.3}$ & 0,860 & 0,000 & Valid \\
& $\mathrm{X}_{1.4}$ & & &
\end{tabular}


Putu Cintya Purnama Dewi dan I Wayan Pradnyantha Wirasedana. Pengaruh...

\begin{tabular}{|c|c|c|c|c|c|}
\hline & & $\mathrm{X}_{1.6}$ & 0,816 & 0,000 & Valid \\
\hline & & $\mathrm{X}_{1.7}$ & 0,859 & 0,000 & Valid \\
\hline & & & 0,841 & 0,000 & Valid \\
\hline & & & 0,882 & 0,000 & Valid \\
\hline \multirow[t]{10}{*}{2} & \multirow[t]{10}{*}{ Kompetensi } & & 0,872 & 0,000 & Valid \\
\hline & & & 0,772 & 0,000 & Valid \\
\hline & & $\mathrm{X}_{2.1}$ & 0,869 & 0,000 & Valid \\
\hline & & $\begin{array}{l}\mathrm{X}_{2.2} \\
\mathrm{X}_{2.3}\end{array}$ & 0,766 & 0,000 & Valid \\
\hline & & $\begin{array}{l}X_{2.4} \\
X_{25}\end{array}$ & 0,826 & 0,000 & Valid \\
\hline & & $\mathrm{X}_{2.6}$ & 0,812 & 0,000 & Valid \\
\hline & & $\begin{array}{l}\mathrm{X}_{2.7} \\
\mathrm{X}_{2.8}\end{array}$ & 0,714 & 0,000 & Valid \\
\hline & & $\begin{array}{l}\mathrm{X}_{2.9} \\
\mathrm{X}_{2}\end{array}$ & 0,866 & 0,000 & Valid \\
\hline & & & 0,761 & 0,000 & Valid \\
\hline & & & 0,893 & 0,000 & Valid \\
\hline \multirow[t]{19}{*}{3} & \multirow{19}{*}{$\begin{array}{l}\text { Good corporate } \\
\text { governance }\end{array}$} & & 0804 & 0,000 & Valid \\
\hline & & & & 0,000 & Valid \\
\hline & & & 0,782 & 0,000 & Valid \\
\hline & & & 0,822 & 0.000 & Valid \\
\hline & & \multirow{15}{*}{$\begin{array}{l}X_{3.1} \\
X_{3.2} \\
X_{3.3} \\
X_{3.4} \\
X_{3.5} \\
X_{3.6} \\
X_{3.7} \\
X_{3.8} \\
X_{3.9} \\
X_{3.10} \\
X_{3.11} \\
X_{3.12} \\
X_{3.13} \\
X_{3.14}\end{array}$} & 0,804 & & \\
\hline & & & 0876 & 0,000 & Valid \\
\hline & & & 0,826 & 0,000 & Valid \\
\hline & & & 0,759 & 0,000 & Vlid \\
\hline & & & 0,877 & & vallu \\
\hline & & & & 0,000 & Valid \\
\hline & & & 0,808 & 0,000 & Valid \\
\hline & & & 0,853 & 0,000 & Valid \\
\hline & & & 0,840 & & \\
\hline & & & 0817 & 0,000 & Valid \\
\hline & & & & 0,000 & Valid \\
\hline & & & 0,866 & 0,000 & Valid \\
\hline & & & 0,843 & (2000 & V1. \\
\hline & & & 0,826 & 0,000 & vallu \\
\hline & & & & 0,000 & Valid \\
\hline
\end{tabular}

Sumber: Data diolah, 2017 
Hasil uji validitas pada Tabel 4. diperoleh nilai correlation total pada masing-masing indikator memiliki nilai signifkansi $0,000<0,05$, sehingga instrumen penelitian pada masing-masing variabel dapat digunakan sebagai alat pengumpulan data karena telah memenuhi kriteria validitas.

Untuk mengukur reliabilitas digunakan uji statistik Cronbach Alpha $(\alpha)$. Nunnally 1994 dalam Ghozali (2016:48) menyatakan bahwa suatu konstruk atau variabel dikatakan reliabel jika memberikan nilai Cronbach Alpha > 0,6. Hasil pengujian reliabilitas ditunjukkan pada Tabel 5. sebagai berikut.

Tabel 5.

Hasil Uji Reliabilitas

\begin{tabular}{clcc}
\hline No & \multicolumn{1}{c}{ Variabel } & $\begin{array}{c}\text { Alpha } \\
\text { Cronbach's }\end{array}$ & Keterangan \\
\hline 1 & Komitmen & 0,936 & Reliabel \\
2 & Kompetensi & 0,945 & Reliabel \\
3 & Good corporate governance & 0,966 & Reliabel \\
\hline
\end{tabular}

Sumber: Data diolah, 2017

Berdasarkan hasil uji reliabilitas instrumen pada Tabel 5. nilai Cronbach's Alpha pada masing-masing variabel lebih besar dari 0,6 sehingga dijelaskan bahwa variabel penelitian telah memenuhi kriteria reliabilitas instrumen.

Untuk mengukur statistik deskriptif dalam penelitian ini menggunakan program SPSS dengan pilihan menu analyze dan sub-menu descriptive statistic.Hasil pengujian analisis deskriptif ditunjukkan pada Tabel 6.

Tabel 6.

Hasil Uji Statistik Deskriptif

\begin{tabular}{lrrrrr}
\hline & N & Minimum & Maximum & Mean & Std. Deviation \\
\hline Kinerja Keuangan & 34 & 1,04 & 5,10 & 3,33 & 1,01 \\
Komitmen & 34 & 9,00 & 28,00 & 19,70 & 4,62 \\
Kompetensi & 34 & 15,00 & 38,00 & 28,17 & 5,80 \\
$\begin{array}{l}\text { Good } \\
\text { governance }\end{array}$ & 34 & 20,00 & 53,00 & 38,29 & 9,08 \\
Valid N (listwise) & 34 & & & & \\
\hline Sumber: Data diolah, 2017 & & & & &
\end{tabular}


Putu Cintya Purnama Dewi dan I Wayan Pradnyantha Wirasedana. Pengaruh...

Nilai rata-rata variabel kinerja keuangan yang diproksikan dengan ROA sebesar 3,33 dengan nilai ROA maksimum yaitu 5,10 dan minimum sebesar 1,04 sedangkan nilai standar deviasi lebih rendah dari nilai rata-rata mengindikasikan bahwa nilai ROA pada LPD tidak mengalami fluktuasi yang tinggi selama periode pengamatan.Nilai rata-rata komitmen sebesar 19,70 dengan nilai maksimum yaitu 28 dan nilai minimum yaitu 15. Nilai standar deviasi pada variabel komitmen yaitu 4,62 lebih rendah dari nilai rata-ata menunjukkan fluktuasi yang rendah.

Nilai rata-rata kompetensi sebesar 28,17 dengan nilai maksimum yaitu 38 dan nilai minimum yaitu 9. Nilai standar deviasi pada variabel kompetensi yaitu 5,80 lebih rendah dari nilai rata-rata menunjukkan fluktuasi yang rendah. Nilai rata-rata good corporate governance sebesar 38,29 dengan nilai maksimum yaitu 53 dan nilai minimum yaitu 20. Nilai standar deviasi pada variabel good corporate governance yaitu 9,08 lebih rendah dari nilai rata-rata menunjukkan fluktuasi yang rendah.

Uji asumsi klasik digunakan untuk menguji kelayakan model yang dibuat sebelum digunakan untuk mrmprediksi, yang meliputi: uji normalitas, uji multikolinieritas, uji heteroskedastisitas, dan uji autokorelasi yang tertera dalam tabel 7. di bawah ini: 
Tabel 7.

Hasil Uji Asumsi Klasik

\begin{tabular}{lll}
\hline \multicolumn{1}{c}{ Uji Asumsi Klasik } & \multicolumn{1}{c}{ Hasil Uji } & Keterangan \\
\hline Uji Normalitas & $\mathrm{p}(0,200)>0,05$ & Berdistribusi normal \\
\hline Uji Multikolinieritas & $\begin{array}{l}\text { Tolerance: }(0,126) ;(0,170) ; \\
(0,106)>0,10\end{array}$ & \\
& VIF: $(7,908) ;(5,892) ;(9,402)$ & \\
& $<10$ & \\
& $\mathrm{p}(0,508) ; \mathrm{p}(0,900) ; \mathrm{p}(0,617)$ & Tidak terjadi \\
Uji Heterokedastisitas & $>0,05$ & heteroskedastisitas
\end{tabular}

Sumber: Data Diolah, 2017

Alat analisis data yang digunakan adalah statistic inference yangbertujuan untuk menguji hipotesis dengan menggunakan Regresi Linier Berganda melalui program komputer SPSS. Hasil pengujian regresi linier berganda ditunjukkan pada Tabel 8 .

Tabel 8.

Hasil Analisis Regresi Linier Berganda

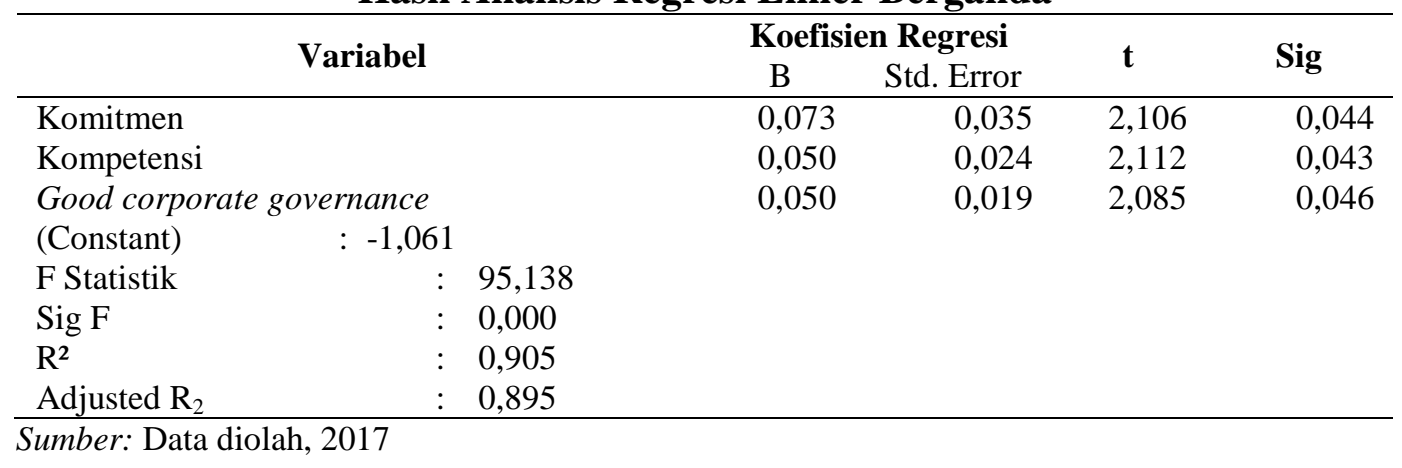

Berdasarkan Tabel 8. hasil analisis regresi linier berganda dapat ditulis persamaan regresi sebagai berikut.

$$
Y=-1,061+0,073 X_{1}+0,050 X_{2}+0,050 X_{3}
$$

Berdasarkan persamaan regresi diperoleh nilai konstanta sebesar -1,061 artinya apabila variabel komitmen, kompetensi dan good corporate governance 
Putu Cintya Purnama Dewi dan I Wayan Pradnyantha Wirasedana. Pengaruh...

tidak mengalami perubahan atau sama dengan konstan, maka kinerja keuangan pada LPD di Abiansemal sebesar -1,061.

Koefisien regresi variabel komitmen sebesar +0,073 dapat diartikan bahwa peningkatan pada variabel komitmen akan cenderung meningkatkan kinerja keuangan pada LPD sebesar 0,073. Koefisien regresi variabel kompetensi sebesar +0,050 dapat diartikan bahwa peningkatan pada variabel kompetensi akan cenderung meningkatkan kinerja keuangan pada LPD sebesar 0,050.Koefisien regresi variabel good corporate governance sebesar $+0,050$ dapat diartikan bahwa peningkatan pada variabel good corporate governance akan cenderung meningkatkan kinerja keuangan pada LPD sebesar 0,50.

Koefisien determinasi mengukur kemampuan model dalam menerangkan variasi variabel dependen. Nilai koefisien determinasi yang kecil berarti kemampuan variabel-variabel independen dalam menjelaskan variasi variabel dependen amat terbatas tetapi apabila nilai koefisien determinasi tinggi berarti variabel independen mampu sepenuhnya menjelaskan variasi dari variabel dependen. Hasil pengujian determinasi ditunjukkan pada Tabel 9.

Tabel 9. Hasil Uji Koefisien Determinasi $\left(\mathbf{R}^{2}\right)$

\begin{tabular}{|c|c|c|c|c|}
\hline Model & $\boldsymbol{R}$ & $R$ Square & $\begin{array}{c}\text { Adjusted } R \\
\text { Square }\end{array}$ & Std. Error of the Estimate \\
\hline 1 &, $951^{\mathrm{a}}$ & ,905 & 895 & ,32742 \\
\hline
\end{tabular}

Sumber: Data diolah, 2017

Berdasarkan hasil pengujian koefisien determinasi ditunjukkan dengan nilai Adjusted $\mathrm{R}^{2}$ sebesar 0,895 atau $89,5 \%$ artinya kontribusi variabel komitmen, kompetensi dan good corporate governance terhadap kinerja keuangan LPD di 
Kecamatan Abiansemal sebesar 89,5\% sedangkan sisanya sebesar 10,5\% dipengaruhi oleh variabel lain yang tidak termasuk dalam model penelitian.

Uji statistik $F$ bertujuan untuk menunjukkan apakah semua variabel independen atau bebas yang dimasukkan dalam model mempunyai pengaruh secara bersama-sama terhadap variabel dependen atau terikat. Hasil uji kelayakan model ditunjukkan pada Tabel 10. sebagai berikut

Tabel 10.

Hasil uji Kelayakan Model

\begin{tabular}{rrrrrrr}
\hline & Model & Sum of Squares & Df & Mean Square & \multicolumn{1}{c}{ F } & \multicolumn{1}{c}{ Sig. } \\
\hline \multirow{2}{*}{1} & Regression & 30,598 & 3 & 10,199 & 95,138 &, $000^{\mathrm{b}}$ \\
& Residual & 3,216 & 30 &, 107 & & \\
& Total & 33,814 & 33 & & & \\
& & & & &
\end{tabular}

Sumber: Data diolah, 2017

Berdasarkan hasil uji kelayakan modal pada Tabel 10. diperoleh nilai $\mathrm{F}$ hitung sebesar 95,138 dengan tingkat signifikansi $0,000<0,05$ artinya variabel komitmen, kompetensi dan good corporate governance mampu menjelaskan kinerja keuangan pada LPD di Kecamatan Abiansemal dan telah memenuhi syarat goodness of fit.

Uji statistik t pada dasarnya menunjukkan seberapa jauh pengaruh satu variabel penjelas atau independen secara individual dalam menerangkan variasi variabel dependen. Hasil pengujian statistik t ditunjukkan pada Tabel 9. sebagai berikut.

Tabel 11.

Hasil Pengujian statistik t

\begin{tabular}{clcc}
\hline No & \multicolumn{1}{c}{ Variabel } & t hitung & Signifikan \\
\hline 1 & Komitmen & 2,106 & 0,044 \\
2 & Kompetensi & 2,112 & 0,043 \\
3 & Good coporate governance & 2,085 & 0,046 \\
\hline
\end{tabular}


Putu Cintya Purnama Dewi dan I Wayan Pradnyantha Wirasedana. Pengaruh...

Hasil pengujian hipotesis pengaruh komitmen terhadap kinerja keuangan LPD di Kecamatan Abiansemal diperoleh nilai t hitung sebesar 2,106 dengan tingkat signifikansi $0,044<0,05$. Hal ini menunjukkan bahwa terdapat pengaruh yang signifikan pada variabel komitmen terhadap kinerja keuangan LPD di Kecamatan Abiansemal.

Hasil pengujian hipotesis pengaruh kompetensi terhadap kinerja keuangan LPD di Kecamatan Abiansemal diperoleh nilai t hitung sebesar 2,112 dengan tingkat signifikansi $0,043<0,05$. Hal ini menunjukkan bahwa terdapat pengaruh yang signifikan pada variabel kompetensi terhadap kinerja keuangan LPD di Kecamatan Abiansemal.

Hasil pengujian hipotesis pengaruh good corporate governance terhadap kinerja keuangan LPD di Kecamatan Abiansemal diperoleh nilai t hitung sebesar 2,085 dengan tingkat signifikansi $0,046<0,05$. Hal ini menunjukkan bahwa terdapat pengaruh yang signifikan pada variabel good corporate governance terhadap kinerja keuangan LPD di Kecamatan Abiansemal.

Hasil pengujian hipotesis menunjukkan bahwa variabel komitmen mempunyai pengaruh yang signifikan pada kinerja keuangan LPD di Kecamatan Abiansemal, hal ini mengindikasikan bahwa peningkatan pada komitmen kerja karyawan di LPD mampu meningkatkan kinerja keuangan.

Berdasarkan pengujian hipotesis pada Tabel 11. variabel komitmen memiliki koefisien regresi sebesar $+0,073$ dengan nilai signifikansi sebesar 0,044 yang lebih kecil dari $\alpha=0,05$. Pengujian ini menunjukkan bahwa variabel komitmen positif dan berpengaruh signifikan pada kinerja keuangan Lembaga 
Perkreditan Desa (LPD). Sehingga $\mathrm{H}_{1}$ diterima. Hal ini menunjukkan bahwa apabila komitmen karyawan semakin baik maka berimplikasi pada semkain baik pula kinerja keuangan LPD.

Hasil penelitian ini sejalan dengan penelitian yang dilakukan oleh Kusumasari dkk (2017) menemukan bahwa komitmen organisasi berpengaruh positif dan signifikan terhadap kinerja Lembaga Perkreditan Desa.

Hasil pengujian hipotesis menunjukkan bahwa variabel kompetensi mempunyai pengaruh yang signifikan pada kinerja keuangan LPD di Kecamatan Abiansemal, hal ini mengindikasikan bahwa kompetensi karyawan yang semakin baik dalam penerapan kinerja mampu meningkatkan kinerja keuangan pada LPD di Kecamatan Abiansemal.

Berdasarkan pengujian hipotesis pada Tabel 11. variabel kompetensi memiliki koefisien regresi sebesar +0,050 dengan nilai signifikansi sebesar 0,043 yang lebih kecil dari $\alpha=0,05$. Pengujian ini menunjukkan bahwa variabel kompetensi positif dan berpengaruh signifikan pada kinerja keuangan Lembaga Perkreditan Desa (LPD). Sehingga $\mathrm{H}_{2}$ diterima. Hal ini menunjukkan bahwa apabila kompetensi karyawan semakin baik maka berimplikasi pada semakin baik pula kinerja keuangan LPD.

Hasil penelitian ini konsisten dengan penelitian yang dilakukan oleh Yudistira dan Siwantara (2012) menyebutkan bahwa kompetensi berpengaruhpositif dan signifikan secara langsung terhadap kinerja karyawan. Hal ini juga didukung oleh penelitian dari Sulistyaningsih (2009) bahwa kompetensi berpengaruh positif terhadap kinerja karyawan. 
Putu Cintya Purnama Dewi dan I Wayan Pradnyantha Wirasedana. Pengaruh...

Hasil pengujian hipotesis menunjukkan bahwa variabel good corporate governance mempunyai pengaruh yang signifikan pada kinerja keuangan LPD di Kecamatan Abiansemal, hal ini mengindikasikan bahwa penerapan tata kelola perusahaan yang baik mencerminkan bahwa perusahaan tidak mengalami permasalahan terutama pada kinerja keuangannya.

Berdasarkan pengujian hipotesis pada Tabel 11. variabel good corporate governance memiliki koefisien regresi sebesar $+0,050$ dengan nilai signifikansi sebesar 0,046 yang lebih kecil dari $\alpha=0,05$. Pengujian ini menunjukkan bahwa variabel good corporate governance berpengaruh positif dan signifikan pada kinerja keuangan Lembaga Perkreditan Desa (LPD). Sehingga $\mathrm{H}_{2}$ diterima. Hal ini menunjukkan bahwa apabila good corporate governance semakin baik dilakukan oleh LPD maka berimplikasi pada semkain baik pula kinerja keuangan LPD.

Hasil penelitian sejalan dengan Penelitian Hindistari (2016) menyatakan bahwa prinsip-prinsip good corporate governance berpengaruh signifikan terhadap kinerja Bank Perkreditan Rakyat Kabupaten Gianyar.

Penelitian ini menghasilkan simpulan mengenai pengaruh komitmen, kompetensi dan good corporate governance pada kinerja keuangan. Hasil dari penelitian ini dapat berkontribusi memperluas pengetahuan dan wawasan serta informasi yang berkaitan dengan komitmen, kompetensi dan good corporate governancedengan menggunakan teori agensi dan di proksikan dengan ROA dapat digunakan untuk menentukan faktor-faktor yang mempengaruhi kinerja 
keuangan. Selain itu teori ini juga dapat digunakan untuk menentukan rencana selanjutnya dalam meningkatkan kinerja keuangan pada LPD .

Pada penelitian ini membuktikan semua variabel yang secara teori memengaruhi kinerja keuangan, hal ini diindikasikan karena responden percaya dengan mempunyai komitmen, kompetensi dan good corporate governance dapat meningkatkan kinerjanya dalam melakukan tugas serta dapat mempermudah dalam mengerjakan pelaporan keuangan yang tersedia pada LPD tersebut.

Penelitian ini diharapkan akan memberikan kontribusi positif bagi semua pihak khususnya LPD di Kecamatan Abiansemal dalam meningkatkan kinerja karyawan dalam mengerjakan tugas-tugasnya. Penelitian ini juga menjelaskan bahwa komitmen, kompetensi dan good corporate governance wajib di terapkan sehingga terciptanya solusi yang akan mempermudah LPD maupun perusahaan perbankan lainnya dalam meningkatkan kinerjanya untuk meningkatkan kesejahteraan masyarakat maupun lembaga yang terkait.

\section{SIMPULAN}

Berdasarkan hasil analisis dan pembahasan penelitian yang telah diuraikan dapat disimpulan bahwa hasil pengujian hipotesis menunjukkan bahwa variabel komitmen mempunyai pengaruh positif terhadap kinerja keuangan LPD di Kecamatan Abiansemal, hal ini mengindikasikan bahwa peningkatan pada komitmen kerja karyawan di LPD mampu meningkatkan kinerja keuangan.

Hasil pengujian hipotesis menunjukkan bahwa variabel kompetensi mempunyai pengaruh positif terhadap kinerja keuangan LPD di Kecamatan Abiansemal, hal ini mengindikasikan bahwa kompetensi karyawan yang semakin 
Putu Cintya Purnama Dewi dan I Wayan Pradnyantha Wirasedana. Pengaruh...

baik dalam penerapan kinerja mampu meningkatkan kinerja keuangan pada LPD di Kecamatan Abiansemal.

Hasil pengujian hipotesis menunjukkan bahwa variabel Good corporate governance mempunyai pengaruh positif terhadap kinerja keuangan LPD di Kecamatan Abiansemal, hal ini mengindikasikan bahwa penerapan tata kelola perusahaan yang baik mencerminkan bahwa perusahaan tidak mengalami permasalahan terutama pada kinerja keuangannya.

\section{REFERENSI}

Ali, K., Akhtar, M.F. and Ahmed, H.Z., 2011. Bank-Specific and Macroeconomic Indicators of Profitability-Empirical Evidence From the Commercial Banks of Pakistan. International Journal of Business and Social Science, 2(6), pp:235-242

Eisenhardt, Kathleem. (1989). Agency Theory: An Assesment and Review. Academy of Management Review, 14. Hal 57-74.

Enceng, Liestyodono, dan Purwaningdyah. 2008. Meningkatkan Kompetensi Aparatur Pemerintah Daerah dalam Mewujudkan Good Corporate Governance.Jurnal Kebijakan dan Manajemen. Vol.2: 12-15

Haque, F., Arun, T., dan Kirkpatrick, C. 2008. Corporate Governance and Capital Markets: A Conceptual Framework. White paper, Heriot-Watt University

Hayati, N. R., Muclis, T. I., and Oktaviani, F. 2009. Comparison Analysis of Financial Performance on Shariah Banking (Case Study In Indonesia and Malaysia). Journal of International Business Academics Consortium Academy of Taiwan Information Systems Research college of Business National Taipe University.

Hill, C. W. L and Thomas M.J. 1992.Stakeholders- Agency Theory.Journal of Management Studies. 29, pp: 131-154

Hindistari, Renitha Ratu. 2016. Pengaruh Penerapan Prinsip-Prinsip Good Corporate Governance pada Kinerja Bank Perkreditan Rakyat Kabupaten Gianyar. E-Jurnal Akuntansi Universitas Udayana. 16(1), h: 101-128.

Husnan, Suad, 2002, Manajemen Keuangan Teori Dan Praktek, Yayasan Badan Penerbit Gajah Mada Yogyakarta, Yogyakarta. 
Jensen, M. C and Meckling, W.H. 1976. Theory of the Firm : Managerial Behavior, Agency Costs and Ownership Structure . Journal of Financial Economics,Oktober, 1976, V. 3, No. 4, pp. 305-360. Avalaible from:http://papers.ssrn.com

Krismaya, Dewi, Kadek. 2014. Pengaruh Penerapan Prinsip-Prinsip Good Corporate Governance Pada Kinerja Keuangan Lembaga Perkreditan Desa Kabupaten Gianyar Bali.E-Jurnal Akuntansi Universitas Udayana, 7(3), h:559-573.

Kusumasari, Sinarwati, Yuniarta. 2017. Pengaruh Penerapan Prinsip-Prinsip Good Corporate Governance, Komitmen Organisasi, Gaya Kepemimpinan, dan Pengawasan Internal terhadap Kinerja Lembaga Perkreditan Desa (Studi Empiris pada LPD Kecamatan Ubud Kabupaten Gianyar). E-Jurnal Akuntansi Universitas Pendidikan Ganesha.

Lubis, Arfan Ikhsan. 2011. Akuntansi Keperilakuan. Jakarta : Salemba Empat

Oliver Hart. 1995. Corporate Governance. Some Theory and Implication.The Economics Jurnal, 105(430), pp:205-213.

Pratiwi, Ni Luh Putu Andriyani, I G.A.M. Asri Dwija Putri, I G.K.A. Ulupui, Eka Ardhani. 2015. Good Corporate Governance and Performance. Proceding The Asian Pacific Conference On Accounting and Finance Bali

Purwani, Tri. 2010. Pengaruh Good Corporate Governance terhadap Kinerja Perusahaan. Fakultas Ilmu Komputer Universitas AKI

Purwanto, Erwan Agus. 2006. Kompetensi Jabatan Struktural. Makalah. Jogyakarta

Robbins, Stephen P dan Judge, Timothy A. 2007.Perilaku Organisasi. Jakarta: Salemba Empat

Sari, Irmala. 2010. Pengaruh Mekanisme Good Corporate Governance terhadap Kinerja Perbankan Nasional. Fakultas Ekonomi Universitas Diponegoro: Semarang

Setyawan, Komang Meitradi. 2013. Pengaruh Good Corporate Governance terhadap Kinerja Keuangan Lembaga Perkreditan Desa (LPD) di Kecamatan Mengwi Kabupaten Badung. E-Jurnal Akuntansi Universitas Udayana.

Simanjuntak, Binsar. 2010. Penerapan Akuntansi Berbasis Akrual di Sektor Pemerintahan di Indonesia. Makalah ini disampaikan dalam Kongres XI Ikatan Akuntan Indonesia. Jakarta. 9 Desember. 
Putu Cintya Purnama Dewi dan I Wayan Pradnyantha Wirasedana. Pengaruh...

Sopiah. 2008. Perilaku Organisasional. Yogyakarta: CV Andi Ofsett

Suartana, I Wayan.2009.Arsitektur Pengelolaan Risiko pada Lembaga Perkreditan Desa (LPD). Udayana University Press

Sukarno, Gendut dan Prasetyohadi. 2004. Analisis Pengaruh Kepuasan Kerja dan Komitmen Organisasi terhadap Semangat Kerja Karyawan, Ventura Vol. 7 No. 3

Sulistyaningsih, Agustini. 2009. Analisis Pengaruh Kepemimpinan, Kompetensi Karakteristik Individu, Locus Of Control dan Penerapan Teknologi Informasi Terhadap Kinerja Pegawai Pada Dinas Pendidikan Kabupaten Klaten. Excellent. (1):1

Wiagustini, Ni Luh Putu. 2014. Manajemen Keuangan. Denpasar : Udayana University Press.

Yudistira. Cokorda Gede Putra, dan I Wayan Siwantara. 2012. Pengaruh Gaya Kepemiminan Transformasional Ketua Koperasi dan Kompetensi Kecerdasan Emosional Manajer Koperasi Terhadap Kepuasan Kerja dan Kinerja Manajer Koperasi di Kabupaten Buleleng. Jurnal Manajemen. Strategi Bisnis dan Kewirausahaan.(6): 1 h:99-108 